\title{
THE ADAPTATIONS OF LASAEA RUBRA (MONTAGU), A SMALL INTERTIDAL LAMELLIBRANCH
}

\author{
By J. E. MORTON \\ Department of Zoology, Queen Mary College, London \\ A. D. BONEY \\ Department of Chemistry and Biology, Plymouth Technical College \\ and E. D. S. CORNER \\ From the Plymouth Laboratory
}

(Text-figs. I-8)

Lasaea rubra is very abundant at Plymouth and has a wide intertidal distribution. It is of small enough size for experiments in which large numbers of animals are needed, and it has recently been studied from several points of view by various workers. Glynne Williams \& Hobart (1952) and Morton (1954) have dealt with its ecology, Oldfield (1955) has given a detailed account of its functional morphology, Ballantine \& Morton (1956) have examined its feeding and filtering, and Morton (1956) has studied its digestive cycle. Much information on its distribution has been given by Fischer (1940).

Life at the level reached by the high spring tide must offer a hard challenge to a bivalve that feeds and respires by filtering. In the present work a study has been made of the ecology of L. rubra in different microhabitats, and experiments have been carried out which shed light on its adaptations to conditions of brief submersion on the upper shore.

\section{INTERTIDAL DISTRIBUTION AND ECOLOGY}

L. rubra is found between the levels of the mean high-water spring and lowwater spring tides. After a survey had been made of the Plymouth area, the rocks in front of the Plymouth Laboratory at the south side of the municipal swimming pool, and Church Reef, Wembury, were selected as two localities giving a representative range of typical habitats. Fig. I shows a simplified diagram of a levelled part of the shore at both places, together with curves, adapted from Colman (1933), showing percentage of exposure at various levels. L. rubra typically avoids extremes of high temperature and low humidity by sheltering in shallow crevices, in empty barnacles or in tufts of the lichen Pygmaea pumila. In this lichen Colman (1940) found its numbers to reach 12,140 per $100 \mathrm{~g}$ of lichen. A dozen or so animals, minute young as well 
as adults, may cluster together, attaching to the substratum or to each other by temporary byssus threads. The species shows a thigmotaxis that must enable it to avoid exposed positions. When placed in sea water the animals creep actively towards points of attachment, or, if no other substrate is available, aggregate with each other.

Table I shows the types of habitat occupied by Lasaea rubra at Wembury and at Plymouth, and indicates the composition of the 'community'. Columns 5 and 6 of the table describe the colour and the nature of the algal infection of the shells; the shells of animals from each habitat usually have such characteristic appearance that the source may be easily recognized.

The histograms in Fig. I illustrate that there are also characteristic size differences between populations from different habitats. The largest modal and maximum sizes were found at Wembury Low and at Wembury High Spring. As already mentioned by Ballantine \& Morton (1956), the animals found at Wembury High Spring are, in fact, larger than those from Wembury High Neap, and special attention has been given to them in this study. The smallest mean size was found in animals from Wembury Pygmaea, and Plymouth Medium High and Plymouth Low Neap animals are only a little larger.

The habitat between and inside the empty shells of Chthamalus stellatus shelters a characteristic fauna both at Plymouth (see Fig. 2) and at Wembury. There is a 'marine element' consisting of four main species, in the following order of numbers at middle Chthamalus level: Lasaea rubra, the isopod Campecopea hirsuta, and the periwinkles Littorina neritoides and young L. rudis. Towards the upper barnacle limit L. neritoides progressively outstrips the others until at the highest level it alone remains. A second faunal element consists of arthropods of land derivation: the most abundant is the small blueblack collembolan Anurida maritima, and, much less frequent, the beetle Micralymma marinum. The bright red mite Bdella interrupta is occasionally found in large numbers and, usually as single individuals, the pseudoscorpion Neobisium maritimum. The primitive marine pulmonate Otina otis, the Wembury form of which has been described by Morton (I954), probably also belongs to this terrestrial element and is frequently found in groups of about half a dozen among Chthamalus bases.

\section{Legend to Fig. I}

Fig. I. Schematic diagrams of shore profiles at Church Reef, Wembury, and the Plymouth foreshore, showing the various habitats mentioned in Table I in relation to tidal levels. At the left are superposed curves from Colman (1933), showing the average percentage of exposure over a fortnightly tidal cycle. The upper curve is that for splash, and the lower one for total submersion. On the right are shown tidal curves for a single spring tide at Plymouth on 4 September 1956, the upper curve for splash, and the lower one for total submersion. At the top of the diagram are shown the histograms for size distribution (shell length in $\mathrm{mm}$ ), of the populations of Lasaea rubra at the different habitats (August I956). (I) Wembury High Spring; (3) Wembury Pygmaea; (4) Wembury Low Neap; (5) Plymouth High Neap; (6) Plymouth Low Neap. 


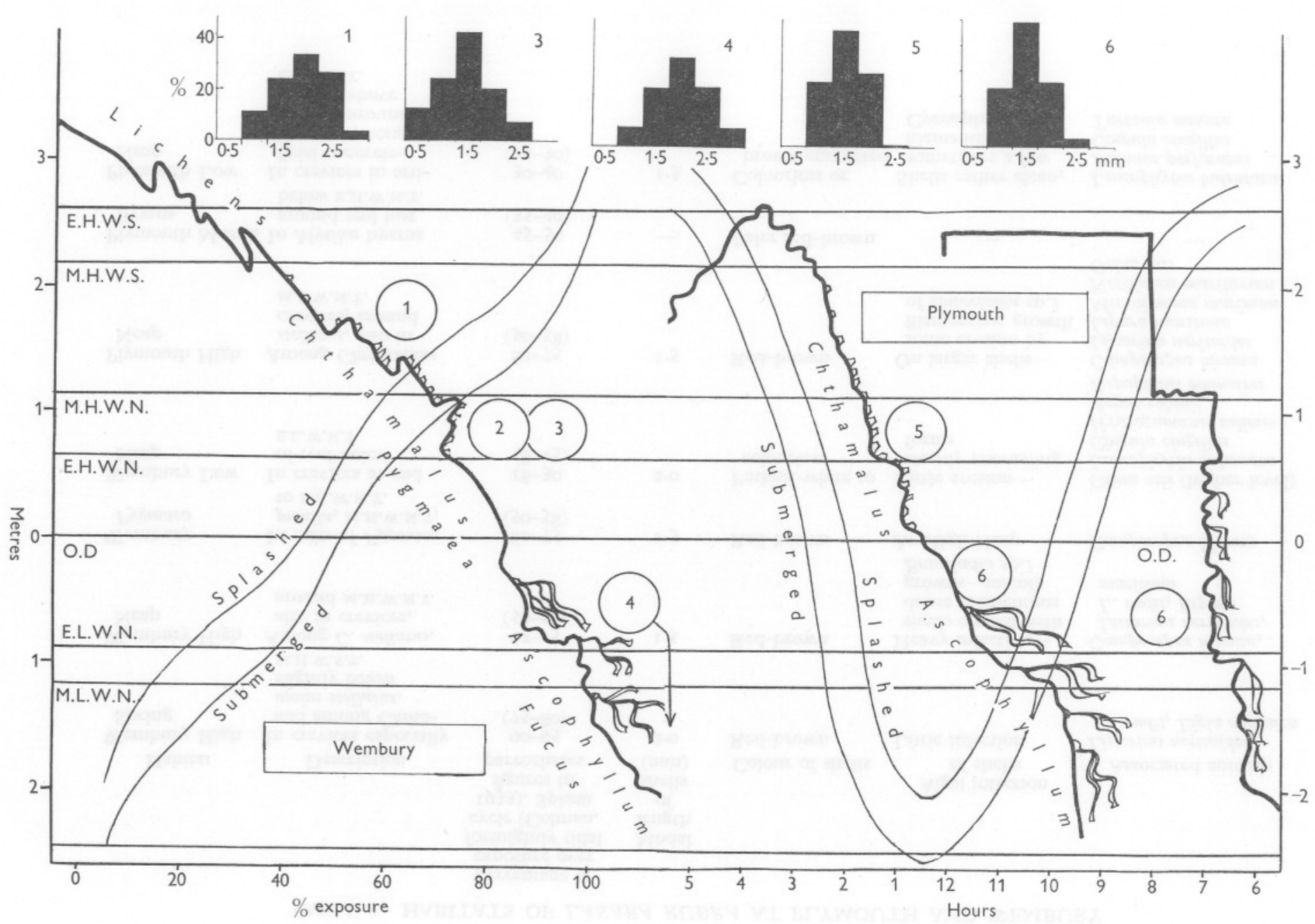

Fig. I 
TABLE 1. HABITATS OF LASAEA RUBRA AT PLYMOUTH AND WEMBURY

Percentage of

exposure over

Habitat

Description

Wembury High In crevices especially and among Chtha-

slightly below

M.H.W.S.T.

Wembury High
Neap

Among C. stellatus,

also in crevices,

around M.H.W.N.T.

Wembury

In tufts of Pygmaea pumila, M.H.W.N.T. to E.H.W.N.T.

Wembury Low In crevices at end Neap of reef below E.L.W.N.T.

Plymouth High Among Chthamalus Neap stellatus, also in crevices, around M.L.W.N.T.

Plymouth Mussel In Mytilus byssus Byssus around and just Plymouth Low In crevices in artiNeap ficial concrete-

limestone congloslightly above E.L.W.N.T. fortnightly tidal

cycle (Colman,

1933). Splash

Modal

length

figures in

parentheses

$90-95$
$(75-80)$

shells

(mm)

$2 \cdot 0$

Colour of shells

Red-brown

$62-75$
$(50-58)$

Red-brown

$62-75$

$(50-58)$

18-30

(8-I5)

$62-75$

$(50-58)$

I.

Red-brown

Red-brown

Pinkish-white to colourless
Algal infection of shells

Little infection

Heavy infectionshells eroded with dense filamentous

growth-mainly

As High Neap

Little erosion-

mainly encrusting forms

On larger shellssome erosion by filamentous growth of Entocladia sp.?

45-50

(35-40)

$30-40$

(25-30)

Paler red-brown

$$
-
$$

Colourless or

Shells rather clean, brown encrusted sometimes a few filamentous Cyanophyceae

Associated animals

Littorina neritoides,

L. rudis, Ligia oceanica

Campecopea hirsuta,

Littorina neritoides,

L. rudis, Lipura

maritima

Campecopea hirsuta

Otina otis (higher level)

Leucophytia bidentata

Cingula cingillus

Hydrogamasus salinus Aepus robinii

Aepophilus bonnairei

Campecopea hirsuta

Littorina neritoides

Lipura maritima

Micralymma marinum

Neobisium maritimum

Otina otis

Leucophytia bidentata

Balanus perforatus

Cingula cingillus

Turtonia minuta 
The lowest habitat of Lasaea rubra on the Plymouth foreshore (Table I) is formed by chips of limestone cemented together at the base of a concrete platform. Here, Balanus perforatus and Elminius modestus are the predominant barnacles, and provide abundant cover for large numbers of palecoloured Lasaea rubra. Chocolate-brown patches of the alga Ralfsia spread over the whole bare surface of the rock and may encrust some of the larger Lasaea shells.

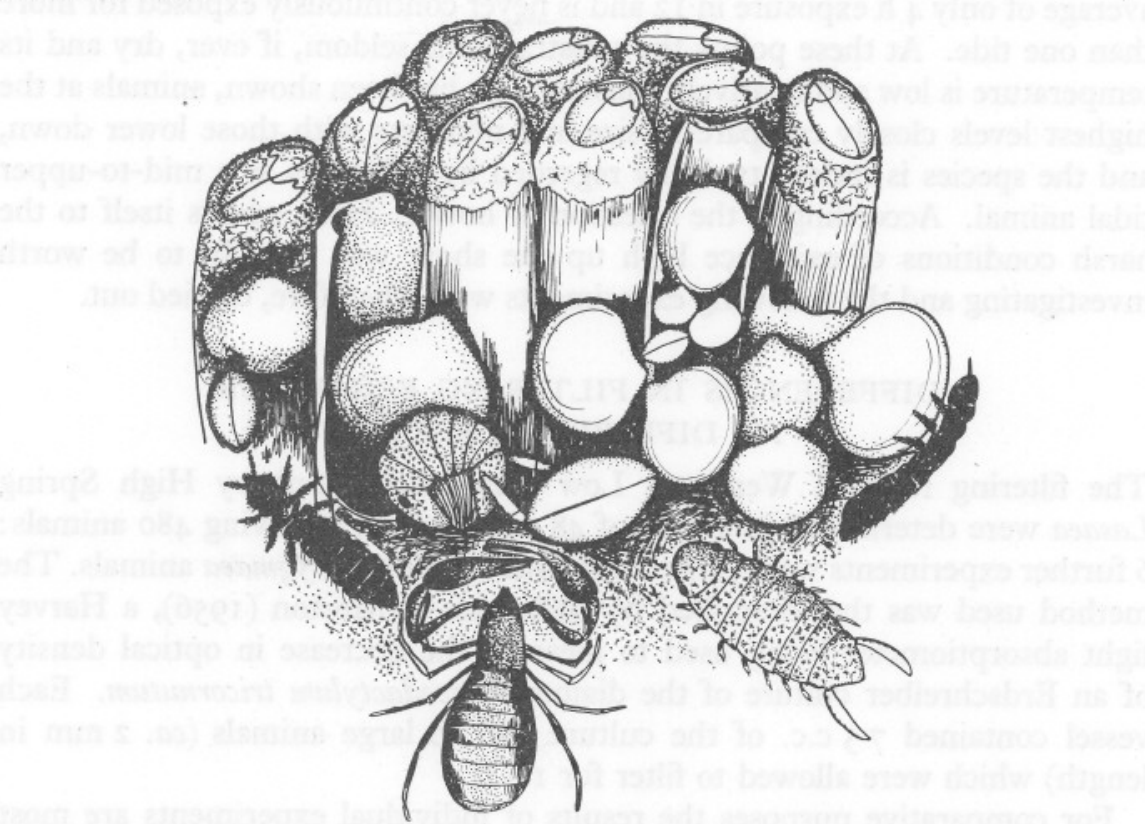

Fig. 2. A group of Lasaea rubra from H.w.N.T. at Plymouth, showing their typical situation between the bases of Chthamalus stellatus. The associated species, Campecopea hirsuta (isopod), Lipura maritima (collembolan), and Neobisium maritimum (pseudoscorpion) are also shown.

The small lamellibranch Turtonia minuta was also found in these habitats. This observation is of interest because the species has not previously been reported as a member of the Plymouth fauna. Although its habits are similar to those of the lowest occurring Lasaea, Turtonia seems to be confined to this low level and thereby differs from Lasaea which is also found farther up the shore. It is smaller than adult Lasaea and is pale yellowish white in colour, with darkened umbones. Superficially it is somewhat like Lasaea, but careful examination shows that it has quite a different shape, the height being only half the length, whereas it is three quarters of the length in Lasaea. Oldfield (I955) has presented a full account of the structure and habits of this bivalve as it occurs at Cullercoats, Northumberland. 


\section{PROBLEMS OF SHORT SUBMERSION AT HIGHER LEVELS}

It has been calculated that $L$. rubra at its upper limit on Church Reef, Wembury (M.H.W.S.T.), receives an average of only $\mathrm{I} h$ submersion in $\mathrm{I}$, and at neap tides may not be totally submerged during a period of 12 consecutive days. Comparable figures for the highest $L$. rubra on Plymouth foreshore are $2.5 \mathrm{~h}$ and 7 days respectively. By contrast, L. rubra at M.L.W.N.T. receives an average of only $4 \mathrm{~h}$ exposure in $\mathrm{I} 2$ and is never continuously exposed for more than one tide. At these points the substratum is seldom, if ever, dry and its temperature is low and relatively constant. As has been shown, animals at the highest levels closely compare in size and numbers with those lower down, and the species is indeed typically regarded by collectors as a mid-to-upper tidal animal. Accordingly, the question of how L. rubra adapts itself to the harsh conditions of existence high up the shore was thought to be worth investigating and the following experiments were, therefore, carried out.

\section{DIFFERENCES IN FILTERING BEHAVIOUR AT DIFFERENT LEVELS}

The filtering rates of Wembury Low Neap and Wembury High Spring Lasaea were determined in a total of 48 experiments involving 480 animals: 6 further experiments were carried out with Wembury Pygmaea animals. The method used was that described by Ballantine \& Morton (1956), a Harvey light absorptiometer being used to measure the decrease in optical density of an Erdschreiber culture of the diatom Phaeodactylum tricornutum. Each vessel contained 7.5 c.c. of the culture and Io large animals $(c a .2 \mathrm{~mm}$ in length) which were allowed to filter for $\mathrm{I} \cdot 5 \mathrm{~h}$.

For comparative purposes the results of individual experiments are most conveniently expressed in units of optical density; conversion into volumes of culture filtered, assuming complete filtration of suspended matter, follows the relationship explained in the previous paper.

Fig. 3 shows the value of optical density at intervals of $0.5, \mathrm{I} \cdot \mathrm{O}$ and $\mathrm{I} \cdot 5 \mathrm{~h}$ for each experiment, and compares the results obtained from studies using Wembury High Spring and Wembury Low Neap Lasaea. For both series of experiments solid diagrams are also given, which express the results of experiments which gave the lowest, mean and highest values observed. These results confirm the difference first found by Ballantine \& Morton (1956) in preliminary experiments on filtering rates. In general, high-tidal animals show, from the beginning of each experiment, a high and uniformly sustained rate of filtering over $\mathrm{I} \cdot 5 \mathrm{~h}$. Low-tidal animals show a very low filtering rate for the first hour, but after this time the rate gradually increases until it closely compares with that of the high-tidal animals. With Wembury High Spring animals Ballantine \& Morton previously found that the filtering rate decreased after an experimental period of $3 \mathrm{~h}$ and became less than that of Wembury Low 
Neap animals. The total volumes filtered by the two sets of animals over $6 \mathrm{~h}$ were thus approximately the same. Obviously, however, the quicker speed of response and initially more rapid filtering rate of high-level Lasaea must be a great advantage to these animals which are covered with water for little more than $\mathrm{I} h$ at any one time.

The filtering behaviour of animals from Wembury Pygmaea (6 experiments) and of others from Plymouth Low Neap was similar to that of the Wembury High Spring animals.
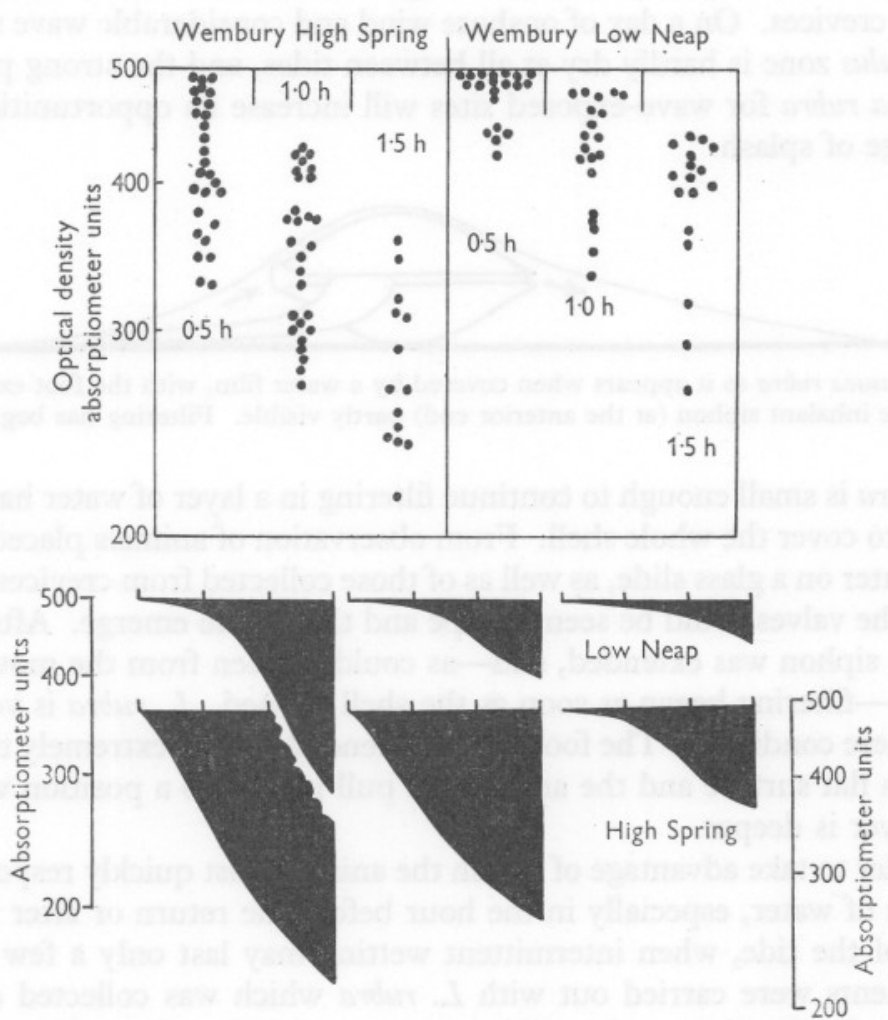

Fig. 3. Results of experiments on the filtering rate of Lasaea rubra from Wembury High Spring and Wembury Low Neap. In each experiment, Io Lasaea rubra were placed in 3.75 c.c. of a culture of Phaeodactylum tricornutum, and allowed to filter for $\mathrm{I} \cdot 5 \mathrm{~h}$ at room temperature (July 1956). Values are expressed in arbitrary absorptiometer units, and indicate the rate of clearing of suspended matter. Upper half: scatter of end values at $0.5, \mathrm{r} \cdot 0$ and $\mathrm{r} \cdot 5 \mathrm{~h}$ of all experiments (left, Wembury High Spring; right, Wembury Low Neap). Lower half: solid graphs from the results of experiments giving the highest, the mean and the lowest values obtained, with animals from Wembury High Spring (top row) and Wembury Low Neap (bottom row). 


\section{RESPONSE TO WAVE SPLASH}

A further factor redressing the difference in filtering times is wave splash, which prolongs the effective period of submersion (Colman, I933). The curves in Fig. I (right) show the results of $\mathrm{I} 2 \mathrm{~h}$ observations of tidal level on the Plymouth foreshore on a day of slight offshore wind. The return of the tide at the Chthamalus level is hastened by about $\mathrm{I}-\mathrm{I} \frac{1}{2} \mathrm{~h}$ by the action of splash and wave surge. The effective uncovering of a given spot is similarly delayed by splash and even longer by sea water lodged in the interstices of barnacles and in small crevices. On a day of onshore wind and considerable wave surge, the Chthamalus zone is hardly dry at all between tides, and the strong preference of Lasaea rubra for wave-exposed sites will increase its opportunities to take advantage of splash.

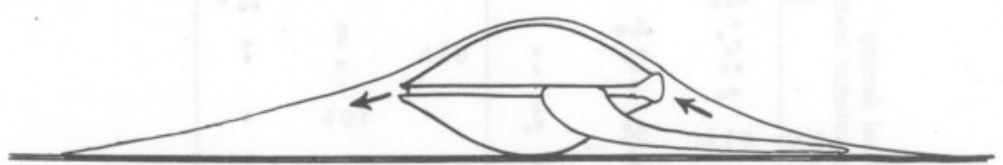

Fig. 4. Lasaea rubra as it appears when covered by a water film, with the foot extended and the inhalant siphon (at the anterior end) partly visible. Filtering has begun.

L. rubra is small enough to continue filtering in a layer of water hardly deep enough to cover the whole shell. From observation of animals placed in a film of sea water on a glass slide, as well as of those collected from crevices wet with splash, the valves could be seen to gape and the foot to emerge. After a short time the siphon was extended, and-as could be seen from the movement of particles-filtering began as soon as the shell opened. L. rubra is very active under these conditions. The foot can be extended into an extremely thin water film on a flat surface and the animal can pull itself into a position where the water layer is deeper.

In order to take advantage of splash the animal must quickly respond to the presence of water, especially in the hour before the return or after the withdrawal of the tide, when intermittent wetting may last only a few minutes. Experiments were carried out with L. rubra which was collected dry, then immediately placed on a glass slide and covered with a film of sea water.

Fig. 5 shows a comparison of the rates of response of Plymouth High Neap and Plymouth Low Neap animals, as estimated from the times needed for the feet to emerge from the shells and for filtering to begin. In $3-4$ min each animal in a sample containing 100 was moving about freely with foot and siphon fully extended.

When treated in this way Plymouth High Neap animals were found to respond significantly faster than those from Plymouth Low Neap. Fig. 5 (below, right) indicates the scatter of values for experiments in which about 60 animals were used and in which the numbers filtering were recorded after 
20, 4080 , and I $20 \mathrm{sec}$. Cumulative histograms are also given which show the highest, the lowest and the mean values recorded after $2 \mathrm{~min}$ in experiments with animals from both levels. The results of typical experiments in which animals were totally submerged in a larger volume of sea water are included in Fig. 5 (upper row) for the purposes of comparison. Fully submerged L. rubra show a rate of response which is faster, but only slightly so, than that of animals covered with water on a slide. Further, the difference between High Neap and Low Neap values is greater in the experiments on slides. Although the power to respond quickly is especially well developed in Lasaea living at high-tidal levels, it is evidently an intrinsic feature of low-tidal animals as well.

Values for the rate of response of Plymouth High Neap L. rubra were plotted against the time for which the animals had previously been exposed on the shore, over the range $0.5-12 \mathrm{~h}$. No obvious correlation was found. L. rubra is evidently able to seize any chance provided by splash or other moisture for filtering purposes, and it is probably advantageous that this power of response is highly developed at all times and independent of previous external conditions.

\section{Relation of response rate to salinity}

Fig. 5 shows percentage values for response to wetting over a period of 5 min for Plymouth High Neap L. rubra, in sea water of salinities ranging from 0.25 to $\mathrm{I} \cdot 75$ normal. A good tolerance, $75 \%$ or more of the normal response rate, was found at salinities between 0.75 and $\mathrm{I} \cdot 25$, within which range the animals appeared to behave normally. The ability to maintain its response to wetting in sea-water samples of widely different salinities may be of considerable importance to an animal which must make use, on the one hand of sea water diluted by rain between tides, and on the other, of sea water in which the salt content has risen by evaporation.

Comparative values are shown in Fig. 5 (lower right) for response by Plymouth High Neap and Plymouth Low Neap L. rubra to sea water of 0.5 normal salinity. The tolerance of half salinity appears to be significantly greater in the high-level animals. This may be partly because the animals at low-tidal levels are less likely to encounter large differences in salinity. A parallel is found in the recent report by Arnold (I957) of a higher response by high-tidal Patella vulgata to stimulus by water of abnormally high or low salinity. With Lasaea rubra, however, the difference may in part be caused by the generally slower response of low-tidal animals, as shown in the experiments described on p. 392. 


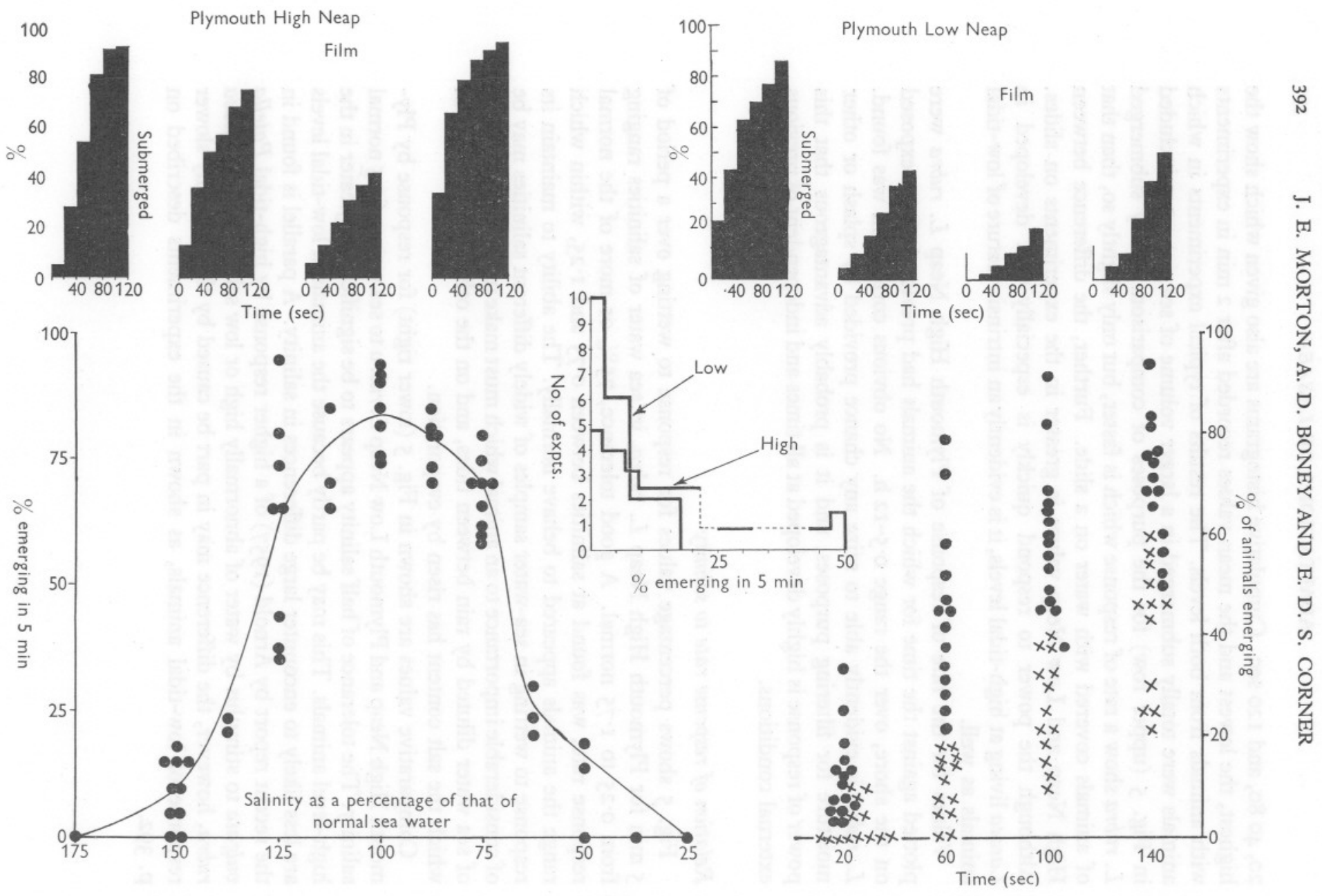

Fig. 5 


\section{RESPIRATORY RATES OF HIGH- AND LOW-TIDAL ANIMALS}

\section{Method}

Animals from Plymouth High Neap, Wembury High Spring and Wembury Low Neap levels were immersed in sea water for $6 \mathrm{~h}$ before measurements of respiratory rates were made. Oxygen uptakes were then followed manometrically at $25^{\circ} \mathrm{C}$ by the direct method of Warburg (Dixon, 1943) and the gas phase used was air. Approximately 75 animals were placed in $3 \mathrm{ml}$. of sea water in the main compartment of each flask and $0.2 \mathrm{ml}$. of $20 \% \mathrm{KOH}$, together with a roll of starch-free filter-paper, was placed in the centre well. Oxygen uptake was found to be independent of shaking rate in the range 50/100 oscillations/min ( $5 \mathrm{~cm}$ traverse), and there was no evidence of damage when animals were inspected at the end of each experiment. Most measurements of oxygen uptake were continued for $8 \mathrm{~h}$, during which time an approximately linear rate was observed (see Fig. 6). Whitaker (1933) reports that when sea water is used as a manometric medium, the $\mathrm{pH}$ may increase from 8.0 to 9.5 as $\mathrm{CO}_{2}$ is removed by the $\mathrm{KOH}$ in the centre well. Robbie (I946), using grasshopper eggs, concludes that the respiring material must offer a rate of $\mathrm{CO}_{2}$-production of approximately $6 \mu \mathrm{l}$. $/ \mathrm{h}$ in order to prevent an excessive shift in $\mathrm{pH}$ in an unbuffered sea-water medium. In the present work it was found that the sea water $\mathrm{pH}$ decreased slightly (usually from $8 \cdot 0$ to $7 \cdot 6$ ) during the $8 \mathrm{~h}$ experimental period, and this was so even when $\mathrm{CO}_{2}$ production was considerably less than $6 \mu \mathrm{l}$./h. Gas exchange alone would not account for this effect. Possibly the animals changed the $\mathrm{pH}$ of the medium by excreting substances that were slightly acidic to sea water

After determinations of oxygen uptake had been made, the animals were left for $\mathrm{I} 2 \mathrm{~h}$ in alcohol strongly acidified $(\mathrm{HCl})$ to fix the tissues and remove the shells. They were then dried to constant weight at $100^{\circ} \mathrm{C}$. The wet weight of an average sample of 100 specimens was about $120 \mathrm{mg}$, and the dry weight without the shell about $10 \mathrm{mg}$. The total nitrogen content of the

\section{Legend to Fig. 5}

Fig. 5. Results of experiments on the rate of response of Lasaea rubra from Plymouth High Neap and Plymouth Low Neap to splash-wetting (August and September 1956). Above. Cumulative histograms showing the response time, by protrusion of the foot, of $L$. rubra barely covered by a film of sea water on a glass slide. In each experiment, Ioo animals were used, and observation continued for 2 min. Left: Plymouth High Neap; right: Plymouth Low Neap. In each group of histograms, the mean, lowest and highest result is represented. At the left of the group is shown, for comparison, a histogram for response time, after total submersion in sea water. Below. Left: a graph showing the relation between the speed of response (percentage response in $5 \mathrm{~min}$ ) and the concentration of sea water, ranging from 0.5 to $\mathrm{I} \cdot 5$ normal. Animals from Wembury High Neap. Right: scatter of end values after 20,60 and Ioo sec, of experiments on response rate in sea-water films on slides. Plymouth High Neap; $\times$, Plymouth Low Neap. Centre. Comparison of response rate in a film of sea water of 0.5 normal salinity, by animals from Plymouth High Neap and Plymouth Low Neap. 
dried animals was determined by the micro-Kjeldahl method and was found to account for 3.36 and $3.30 \%$ of the shell-free dry weight of high and of low animals respectively. All oxygen uptakes were then expressed as $Q_{\mathrm{O}_{2}}(\mathrm{~N})$, i.e. $\mu \mathrm{l} . \mathrm{O}_{2} / \mathrm{h} / \mathrm{mg}$ tissue-N.

Preliminary experiments showed that the rate of oxygen uptake of animals at all levels varied inversely with the number of animals used in the experiment. Thus, high-level samples over the range $2.5-20 \mathrm{mg}$ dry weight gave $Q_{\mathrm{O}_{2}}$ values between 2.5 and $\mathrm{I} \cdot 2 \mu \mathrm{l} . \mathrm{O}_{2} / \mathrm{h} / \mathrm{mg}$ dry wt. respectively: the corresponding values for low-level animals over the same range of biomass were between $\mathrm{I} \cdot 3$ and $0.45 \mu \mathrm{l} . \mathrm{O}_{2} / \mathrm{h} / \mathrm{mg}$ dry wt. The influence of the quantity of animals on the rate of oxygen uptake was probably related to the tendency of L. rubra to aggregate, thereby reducing the free exchange of respiratory gases. Shaking the flasks very vigorously ( $c a$. 120 oscillations $/ \mathrm{min}$ ) did not prevent aggregation, and accordingly, in order to carry out an adequate comparison of respiratory rates, it was necessary to use in all experiments the same narrow range of biomass. It was found that quantities of animals from each level yielding a dry weight of 5-10 mg gave within each group a very comparable level of results. From each tidal level studied, some 20 or more determinations were made, using approximately 1500 animals in each group of experiments.

\section{Results}

From the findings summarized in Fig. 6 it will be seen that there is a considerable difference in the rates of oxygen uptake of the medium- and lowlevel animals, and a smaller but significant difference between the rates of animals from medium high and high levels. Mean $Q_{\mathrm{O}_{2}}$ values are shown in Table 2 and indicate that animals from the low level possess a rate of respiration approximately $50 \%$ of that shown by those from the high level.

TABLE 2. COMPARISON OF THE FILTERING AND RESPIRATORY RATES OF LASAEA RUBRA WITH THOSE OF MYTILUS EDULIS

Mean $Q_{\mathrm{O}_{2}}(\mathrm{~N})$ values $\left(\mu \mathrm{l} . \mathrm{O}_{2} / \mathrm{h} / \mathrm{mg}\right.$ tissue-N)

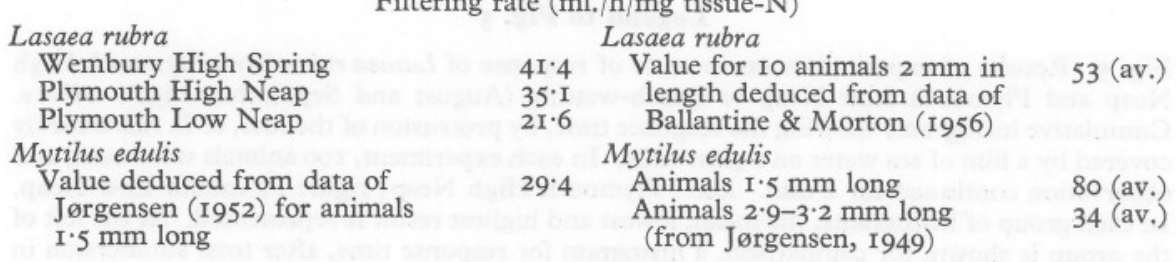

Using the results of a recent study by Jørgensen (I952) it has been possible to deduce $Q_{\mathrm{o}_{2}}(\mathrm{~N})$ values for Mytilus edulis over a wide range of body size. The value corresponding to newly metamorphosed animals of the same size as the Lasaea used in the present work (ca. I.5 mm) is included in Table 2 
and shows that the respiration rates of the two species are very similar. A similar parallel between the filtering rates of larger Mytilus edulis $(\mathbf{I} \cdot 5-2 \cdot 9 \mathrm{~cm}$ length) was found by Jørgensen (I949), and Ballantine \& Morton's findings for Lasaea rubra (1956).
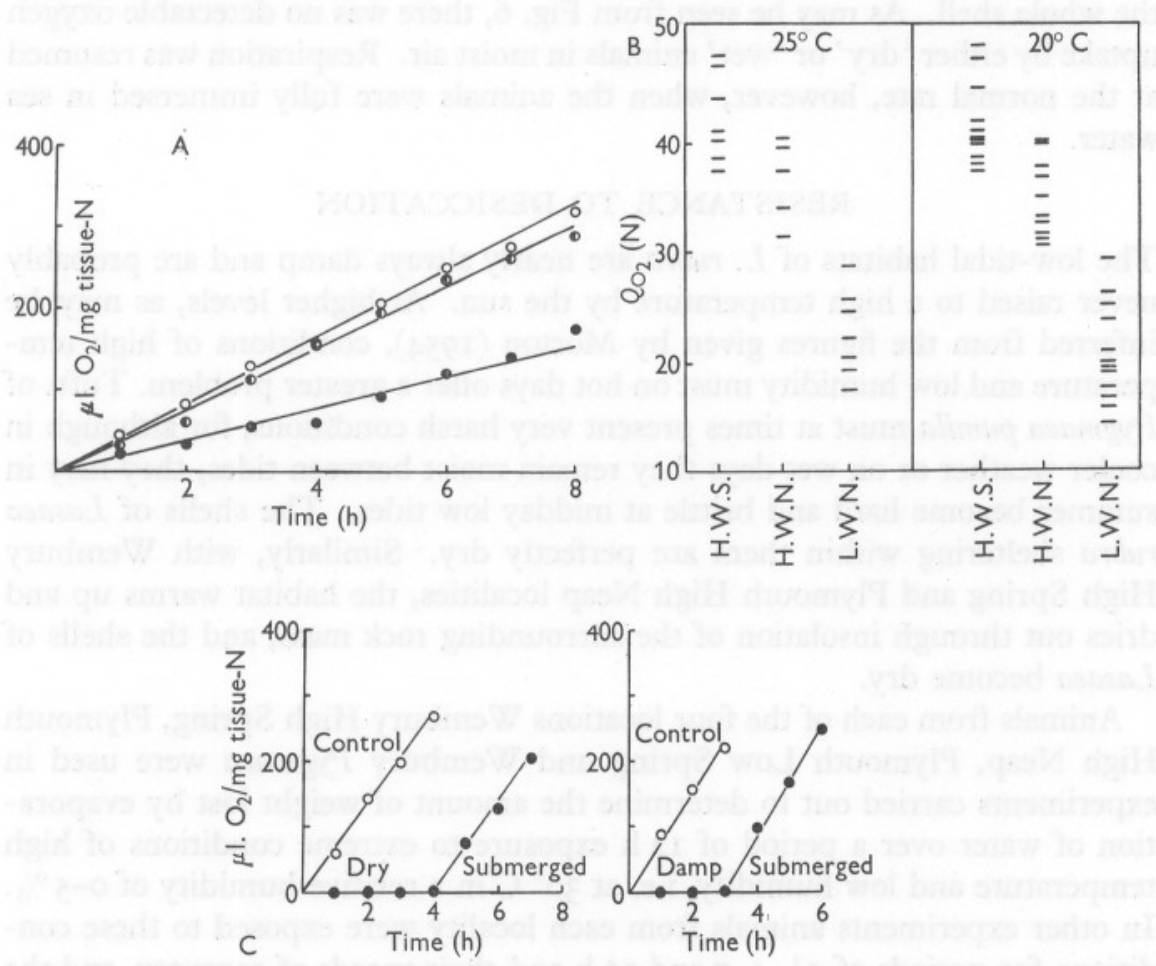

Fig. 6. (A) Respiration of High Spring (O-O), High Neap (Lasaea rubra. Each point is a mean value of six determinations made at $20^{\circ} \mathrm{C}$ using 5-10 $\mathrm{mg}$ shell-less dry weight of animals. (B) Scatter of $Q_{\mathrm{O}_{2}}(\mathrm{~N})$ values observed for $L$. rubra from three tidal levels. Left: experiments carried out at $25^{\circ} \mathrm{C}$ with 8-10 $\mathrm{mg}$ shell-less dry weight of animals for each determination. Right: experiments, conducted at $20^{\circ} \mathrm{C}$, in each of which 5-IO mg shell-less dry weight of animals was used. (C) Respiration of High Spring L. rubra when dry (left), damp (right) and when submerged in sea water. $\bigcirc-\bigcirc$, Animals submerged at once; - animals submerged after $4 \mathrm{~h}$ in a dry state (left) or $3 \mathrm{~h}$ in the damp state (right). Each point is the mean of four determinations carried out at $25^{\circ} \mathrm{C}$ with $5 \mathrm{mg}$ shell-less dry weight of animals.

\section{Respiration of 'dry' and 'wet' animals in moist air}

Approximately 40 L. rubra from Wembury High Spring level (ca. 3 mg dry wt.) were placed, after careful drying of the shells, in Warburg flasks equipped with two side-arms. In each side-arm was placed $\mathrm{I} \cdot 5 \mathrm{ml}$. of sea water. To each of three other flasks the same number of animals was added, immersed as usual in $3 \mathrm{ml}$. of sea water. Oxygen uptakes of dry and submerged animals 
were then measured for $3 \mathrm{~h}$, after which time the water from the side-arms was tipped upon the dry animals, and measurements of oxygen consumption continued for a further $3 \mathrm{~h}$. A second experiment was made in which, instead of 'dry' L. rubra, the animals used lay in a water film insufficient to immerse the whole shell. As may be seen from Fig. 6, there was no detectable oxygen uptake by either 'dry' or 'wet' animals in moist air. Respiration was resumed at the normal rate, however, when the animals were fully immersed in sea water.

\section{RESISTANCE TO DESICCATION}

The low-tidal habitats of L. rubra are nearly always damp and are probably never raised to a high temperature by the sun. At higher levels, as may be inferred from the figures given by Morton (1954), conditions of high temperature and low humidity must on hot days offer a greater problem. Tufts of Pygmaea pumila must at times present very harsh conditions, for although in cooler weather or on wet days they remain moist between tides, they may in summer become hard and brittle at midday low tides. The shells of Lasaea rubra sheltering within them are perfectly dry. Similarly, with Wembury High Spring and Plymouth High Neap localities, the habitat warms up and dries out through insolation of the surrounding rock mass, and the shells of Lasaea become dry.

Animals from each of the four locations Wembury High Spring, Plymouth High Neap, Plymouth Low Spring and Wembury Pygmaea were used in experiments carried out to determine the amount of weight lost by evaporation of water over a period of $\mathrm{I} 2 \mathrm{~h}$ exposure to extreme conditions of high temperature and low humidity, i.e. at $30^{\circ} \mathrm{C}$ in a relative humidity of $0-5 \%$. In other experiments animals from each locality were exposed to these conditions for periods of $\mathrm{I} \frac{1}{2}, 4,7$ and $\mathrm{I} 2 \mathrm{~h}$ and their speeds of recovery, and the percentages of the totals which recovered when they were replaced in sea water, were then determined. Recovery was assumed to have occurred the moment the foot or the siphon emerged.

\section{Method}

In studies of the rates of water loss, a thermogravimetric method was used in which the change of weight was measured by counterbalancing electromagnetically, as described by Gregg (I955). The balance was fixed to a wooden frame over a bath of water, the temperature of which was regulated by a SunVic thermostatic control linked to an immersion heater. In the bath was placed a chamber (500 c.c.) in which the humidity was controlled by the use of appropriate concentrations of sulphuric acid. A wire gauze reaction vessel was placed in the humidity chamber, and suspended from the underside of a balance pan. In each experiment a sample of about 200 aggregated animals, drained of surplus water and with their shells only slightly wet, was placed in 
the reaction vessel. The fresh weight was determined in the previously weighed reaction vessel. The humidity chamber was then closed by a divided cork, and weight loss was measured at intervals by briefly removing the cork and equilibrating the reaction vessel against the magnet of the balance.

Fig. 7 shows the curves for water loss over an experimental period of II $h$, calculated from the beginning of the second hour in the drying vessel (it was considered that most of the water loss after the first hour could be accounted for by the removal of water from the surface of the shells and the pallial

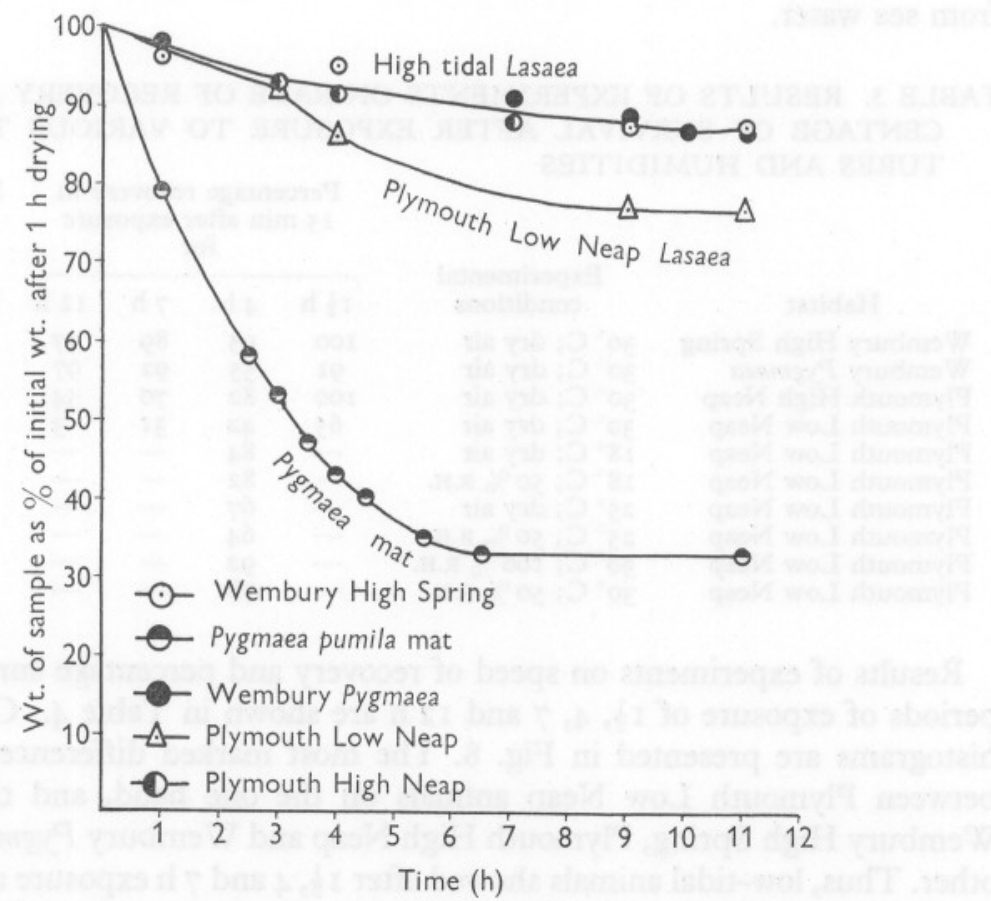

Fig. 7. Graphs showing loss of weight, by evaporation of water, of Lasaea rubra from various habitats. A sample of about 200 animals was exposed over a period of $12 \mathrm{~h}$ to a temperature of $30^{\circ} \mathrm{C}$ in an atmosphere of $0-5 \%$ relative humidity. Weights are expressed as percentages of the weight of the sample after the first hour of drying, during which only surface water evaporated. The lower curve shows the values for the loss of weight by the intertidal lichen $P$. pumila under the same experimental conditions.

cavity). It is apparent that even in the high-tidal samples, the shells are unable to remain perfectly sealed against prolonged exposure to dry air, and, in fact, most of the animals replaced in water after more than $3 \mathrm{~h}$ drying at first floated with the umbones down. An air bubble could be seen in the pallial cavity, which was released when the animal extended its foot. Water loss from Plymouth Low Neap animals appeared to be about twice that from the 
samples from the other three locations, amounting in II h to $23 \%$ by weight. In animals from Plymouth High Neap, Wembury High Spring and Wembury Pygmaea, the curves for water loss were almost identical over the II $h$ experimental period. Thus, the low-tidal animals appear to be less able to keep their shells tightly closed over a long period. A behavioural difference in Plymouth Low Neap animals could sometimes be noticed which confirmed this result, namely that when these Lasaea were left in the dry state they did not close their shells as quickly as did those from higher levels, and occasionally their shells remained open for a considerable time after the animals were removed from sea water.

TABLE 3. RESULTS OF EXPERIMENTS ON RATE OF RECOVERY AND PERCENTAGE OF SURVIVAL AFTER EXPOSURE TO VARIOUS TEMPERATURES AND HUMIDITIES

\begin{tabular}{|c|c|c|c|c|c|c|c|}
\hline \multirow[b]{2}{*}{ Habitat } & \multirow{2}{*}{$\begin{array}{l}\text { Experimental } \\
\text { conditions }\end{array}$} & \multicolumn{4}{|c|}{$\begin{array}{l}\text { Percentage recovery in } \\
\text { I5 min after exposure } \\
\text { for }\end{array}$} & \multicolumn{2}{|c|}{$\begin{array}{c}\text { Percentage } \\
\text { dead } \\
\text { after }\end{array}$} \\
\hline & & $\mathrm{I}_{2}^{\frac{1}{2}} \mathrm{~h}$ & $4 \mathrm{~h}$ & $7 \mathrm{~h}$ & $\mathrm{I} 2 \mathrm{~h}$ & $7 \mathrm{~h}$ & I $2 \mathrm{~h}$ \\
\hline Wembury High Spring & $30^{\circ} \mathrm{C}$; dry air & 100 & 95 & 89 & 97 & 0 & o \\
\hline Wembury Pygmaea & $30^{\circ} \mathrm{C}$; dry air & $9 \mathrm{I}$ & 5 & 92 & 97 & 0 & 0 \\
\hline Plymouth High Neap & $30^{\circ} \mathrm{C}$; dry air & 100 & 82 & 70 & 54 & 0 & 24 \\
\hline Plymouth Low Neap & $30^{\circ} \mathrm{C}$; dry air & 65 & 42 & $3 I$ & 3 & 5 & 50 \\
\hline Plymouth Low Neap & $18^{\circ} \mathrm{C}$; dry air & - & 84 & - & - & - & - \\
\hline Plymouth Low Neap & I $8^{\circ} \mathrm{C} ; 50 \%$ R.H. & - & 82 & - & - & - & - \\
\hline Plymouth Low Neap & $25^{\circ} \mathrm{C}$; dry air & - & 67 & - & - & - & - \\
\hline Plymouth Low Neap & $25^{\circ} \mathrm{C} ; 50 \%$ R.H. & - & 64 & - & - & - & - \\
\hline Plymouth Low Neap & $30^{\circ} \mathrm{C} ; 100 \%$ R.H. & - & 92 & - & - & - & 一 \\
\hline Plymouth Low Neap & $30^{\circ} \mathrm{C} ; 50 \%$ R.H. & 一 & 78 & - & 一 & - & - \\
\hline
\end{tabular}

Results of experiments on speed of recovery and percentage survival after periods of exposure of $\mathrm{I} \frac{1}{2}, 4,7$ and $\mathrm{I} 2 \mathrm{~h}$ are shown in Table 4 . Cumulative histograms are presented in Fig. 8. The most marked differences are seen between Plymouth Low Neap animals on the one hand, and those from Wembury High Spring, Plymouth High Neap and Wembury Pygmaea on the other. Thus, low-tidal animals showed after $\mathrm{I} \frac{1}{2}, 4$ and $7 \mathrm{~h}$ exposure a markedly slower rate of recovery than that of high-level animals when placed in sea water. After $7 \mathrm{~h}, 5 \%$ of the low-level animals had died, but the remainder eventually recovered. After $\mathrm{I} 2 \mathrm{~h}$ exposure, $50 \%$ had died and although the remaining animals recovered they did so at a very slow rate. By contrast, in experiments with Wembury High Spring and Wembury Pygmaea animals it was found that even after prolonged exposure ( $12 \mathrm{~h}$ ) there was almost complete recovery $(80-90 \%)$ within $12 \mathrm{~min}$ of immersion in sea water. In experiments with Plymouth High Neap animals it was found that $24 \%$ of the sample were dead after exposure for $12 \mathrm{~h}$ and, further, the recovery of the remainder from this, and shorter, periods of exposure was slower than that observed in experiments with Wembury High Spring and Wembury Pygmaea animals. 

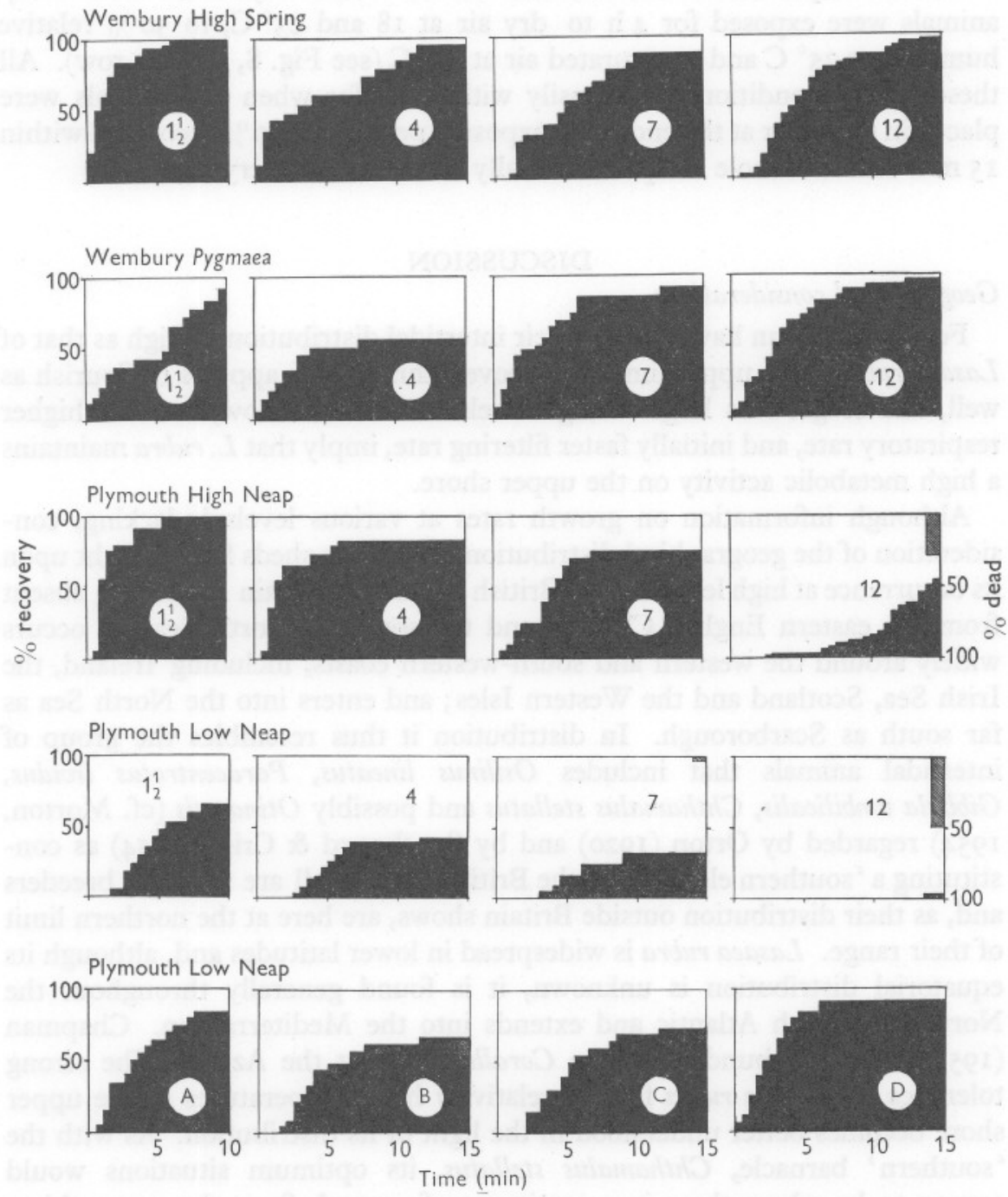

Fig. 8. Cumulative histograms showing the rate of recovery on return to sea water of Lasaea rubra which had been exposed to high temperatures and low humidities. Rows $\mathrm{I}-4$ describe the recovery of animals after exposure to an atmosphere of $0-5 \%$ relative humidity at $30^{\circ} \mathrm{C}$. Samples were returned to sea water after $\mathrm{I} \cdot 5,4,7$ and $\mathrm{I} 2 \mathrm{~h}$ as indicated on each diagram. Row 5 describes the recovery of animals exposed for $4 \mathrm{~h}$ to $0-5 \%$ relative humidity at $18^{\circ} \mathrm{C}$ (A); $50 \%$ relative humidity at $25^{\circ} \mathrm{C}(\mathrm{B}) ; 0-5 \%$ relative humidity at $25^{\circ} \mathrm{C}$ (C) and $100 \%$ relative humidity at $30^{\circ} \mathrm{C}(\mathrm{D})$. 
Further experiments were carried out in which Plymouth Low Neap animals were exposed for $4 \mathrm{~h}$ to dry air at $\mathrm{I} 8$ and $25^{\circ} \mathrm{C}$, to $50 \%$ relative humidity at $25^{\circ} \mathrm{C}$ and to saturated air at $30^{\circ} \mathrm{C}$ (see Fig. 8, bottom row). All these sets of conditions were easily withstood, for when the animals were placed in sea water at the end of the exposure period, $60-90 \%$ recovered within I5 min and the whole sample eventually recovered in every case.

\section{Geographical considerations}

\section{DISCUSSION}

Few bivalves can have pushed their intertidal distribution as high as that of Lasaea rubra at its upper limit. Moreover, this species appears to flourish as well, and to grow as large at high levels as it does at low, and the higher respiratory rate, and initially faster filtering rate, imply that $L$. rubra maintains a high metabolic activity on the upper shore.

Although information on growth rates at various levels is lacking, consideration of the geographical distribution of $L$. rubra sheds further light upon its occurrence at high levels on the British shore. In Britain L. rubra is absent from the eastern English Channel and the southern North Sea. It occurs widely around the western and south-western coasts, including Ireland, the Irish Sea, Scotland and the Western Isles; and enters into the North Sea as far south as Scarborough. In distribution it thus resembles the group of intertidal animals that includes Osilinus lineatus, Paracentrotus lividus, Gibbula umbilicalis, Chthamalus stellatus and possibly Otina otis (cf. Morton, 1954) regarded by Orton (1920) and by Southward \& Crisp (1954) as constituting a 'southern element' in the British fauna. All are summer breeders and, as their distribution outside Britain shows, are here at the northern limit of their range. Lasaea rubra is widespread in lower latitudes and, although its equatorial distribution is unknown, it is found generally throughout the North and South Atlantic and extends into the Mediterranean. Chapman (1955) found it abundant in the Corallina turf at the Azores. The strong tolerance by Lasaea rubra for the relatively high temperatures of the upper shore becomes better understood in the light of its distribution. As with the 'southern' barnacle, Chthamalus stellatus, its optimum situations would appear to be where there is a maximum of warmth from the sun, subject always to protection from very prolonged high temperatures.

\section{Adaptations}

If, as its geographical distribution suggests, Lasaea has a preference for the English upper shore, considerable interest attaches to several adaptations which might help the animal to offset the adverse conditions of brief submersion and shortened filtering and respiring times. Small size is in itself an advantage which must enable the animal to filter from small volumes of water 
intermittently splashed on to it between tides. In addition, there are behavioural adaptations such as rapid response to wetting-better developed at upper levels in the Plymouth population-which equip Lasaea as an 'opportunist' species able to take immediate advantage of splash. Southward (personal conversation) finds the same adaptation in high level Chthamalus stellatus. A further adaptation is that of site selection: thigmotaxis, negative phototaxis and preference for moisture all lead Lasaea rubra to aggregate in small crevices and in lichen tufts where splash probably collects and where desiccation is less likely. Activity in a rather wide salinity range (see p. 392) may also enable Lasaea to take advantage of splash diluted with rain water or to continue filtering after salinity has risen slightly by evaporation.

Our experiments suggest that animals at higher levels possess certain physiological adaptations concerned with filtering and respiration which must also protect them against the rigours of short submersion. Thus, studies of filtering rates disclose that whereas animals from high up the shore begin to filter rapidly as soon as they are wetted, low-tidal animals at first show a much lower filtering rate. After approximately $3 \mathrm{~h}$, however, low-level animals build up a filtering rate approaching that of higher animals. These findings, while not implying an intrinsic difference between the filtering rates of high- and lowlevel Lasaea, do, however, draw attention to the much quicker response of high-tidal animals.

In contrast to the feeding-rate studies, investigation of the respiratory rates of L. rubra from Wembury High Spring, Plymouth High Neap and Plymouth Low Neap levels has shown marked intrinsic differences. Thus, animals from high up the shore respire at approximately twice the rate of Low Neap animals. Interest also attaches to the further finding that these high-level animals are unable to respire in moist air when damp or dry; evidently the price of hightidal existence is paid not by using atmospheric oxygen, but by developing a rapid rate of aquatic respiration during brief periods of submersion.

There seems a need to explain why no respiration could be detected when animals are covered by a thin layer of water, though in this state filtering may be taking place. However, absence of measurable respiration need not imply absence of feeding, because collection of solid particles by the gill-although a ciliary process-must be relatively much faster than gaseous exchange. It is known that L. rubra is able to clear all particles from its own volume of water in 2 min. A few minutes' filtering of splash may thus be valuable from the point of view of feeding. The animal ingests large amounts of bottom detritus, such as may be stirred into suspension in falling splash, in addition to the rich phytoplankton found in Plymouth water samples at or near the substratum where Lasaea was collected (Ballantine \& Morton, 1956).

Experiments on resistance to desiccation and recovery from exposure to high temperatures have shown that Wembury High Spring and Wembury Pygmaea animals are well able to withstand conditions of high temperature 
and low humidity far more unfavourable than any which can occur in the field. In addition, it has been found that whereas Plymouth High Neap animals are only slightly less resistant than the Wembury High Spring and Wembury Pygmaea Lasaea to harsh experimental conditions, Plymouth Low Neap animals are much less resistant than the Wembury high-level Lasaea in this respect. These differences accord with tidal position (see Fig. 8), and reveal a clear physiological difference between populations at high and low levels. The shell pigmentation may be a relevant factor in temperature resistance, and it is hoped to investigate this further. Resistance to desiccation at high levels must depend upon tight closing of the shell when the animals are dry, and this evidently allows no respiratory exchange with damp air, or even when the shells are covered with a water film. Aerial respiration by a damp body surface must be paid for by restriction to 'safe' habitats of high humidity.

\section{Comparison with other species}

Other animals sharing the high-level habitat of L. rubra are the barnacle Chthamalus stellatus and the small periwinkle Littorina (Melarhaphe) neritoides. In some features of their ecology these bear comparison with Lasaea rubra. Chthamalus stellatus is also a filter feeder, but appears (see Monterosso, 1928) to be able to respire to some extent in a moist atmosphere. No detailed data are available for comparative respiration at various levels. Southward (1955), in a study of the influence of tidal level on cirral activity of barnacles, finds that whereas Elminius modestus and Balanus balanoides have a higher rate of cirral beat at low-tidal levels, Chthamalus stellatus-except at one locality-maintains an equally high rate at high levels. This feature of $C$. stellatus may offer partial compensation for short submersion time. A further advantage enjoyed by high-level $C$. stellatus - as compared with Lasaea rubra - must be its faster method of filtering, by means of cirri, under muscular control. A forthcoming account by Southward of filtering mechanisms of barnacles should make a comparison easier. Littorina neritoides depends on a film of moisture for feeding (Lysaght, I94I). It crops small algae and lichens with its radula, and does not need either submersion or heavy splash. Respiration can take place in moist air, although Fischer, Duval \& Raffy (1933) have shown that it is five or six times higher in water than in air. Patané (1933) finds that L. neritoides regains activity after a few minutes in water, following 5 months' exposure to air.

Both the barnacle and the periwinkle reproduce by liberating free-swimming larvae. Lasaea rubra incubates the young between the gill lamellae. A free-swimming stage permits wide distribution and site selection, and such an opportunity for intermixture of extremes of the population and exchange of settling sites seems to be lacking in L. rubra. Young animals settle near the parent, and this tendency to isolation of small populations offers a method by 
which physiological differences within the species-for example, in pigmentation, and in respiratory rate-might lead to ecological subspeciation.

A recent study by Segal, Rao \& James (I953) of differences in water propulsion by Mytilus californianus at three depths, 'deep water at $30 \mathrm{ft}$.', 'low intertidal' and 'mid-intertidal', reveals higher activity as depth increases. The authors correlate this finding with temperature adaptation in a poikilothermal animal. But this situation is hardly comparable with that of intertidal Lasaea rubra, subjected as it is to long exposure on the upper shore. The lowest population of L. rubra corresponds in level to the highest ('mid-intertidal') population of Mytilus. The 'mid-intertidal' Mytilus are, moreover, smaller than the 'low-intertidal', and these in turn are smaller than the deep ones. It would appear that $M$. californianus is a species restricted as to size and probably metabolism, on entering the intertidal zone from off-shore. Lasaea rubra, however, with a wholly intertidal distribution, holds its own well at high water. A relevant fact is that the highest filtering rates recorded were from high-tidal animals at an experimental temperature of $22^{\circ} \mathrm{C}$ (Ballantine \& Morton, I956).

The mode of life, especially the reproduction and rate of growth, of Lasaea rubra invites further study. But from what we already know of its adaptations to life in the upper tidal zone, this bivalve seems to stand out-physiologically as well as geographically - as a member of the rather distinct 'southern component' of our intertidal fauna.

It is a pleasure to express our thanks to $\mathrm{Mr}$ E. R. March of Plymouth Technical College for constructing the electromagnetic sorption balance used in some of our experiments. Two of us (J.E.M.) and (A.D.B.) have been using London University Tables at the Plymouth Laboratory, and one of us (E. D. S. C.) is indebted to International Paints Ltd. for a Research Fellowship. We are most grateful to the Director and many members of the staff of the Plymouth Laboratory for the encouragement and helpful advice they have given us throughout the research.

\section{SUMMARY}

A study has been made of the ecology of the small intertidal lamellibranch Lasaea rubra at various tidal levels at Plymouth and Wembury. In addition, experiments have been carried out to investigate physiological and behavioural differences arising from varying amounts of submersion at different tidal levels, and the following findings have been made.

During the first hour after their submersion by sea water, L. rubra from high up the shore filter at a rate approximately twice that of animals which live lower down. After $2 \mathrm{~h}$, however, both sets of animals filter at the same rate.

High-level animals respond significantly faster to wetting by splash and can tolerate a considerable range of salinity. They also respire at a rate 
approximately twice that of low-level animals. Respiration, however, is not detectable when the animal is not immersed in sea water.

L. rubra from all levels show a good resistance to desiccation when exposed to high temperature and low humidity, but over a $\mathrm{I} 2 \mathrm{~h}$ period low-level animals lose more water by evaporation. Moreover, when the low-level animals are subjected to these harsh experimental conditions they show a lower rate of recovery and a lower percentage of survival.

These findings are discussed with reference to the geographical distribution of Lasaea rubra and its status as a warmth-loving member of a southern faunal element.

\section{REFERENCES}

ARnold, D. C., I957. The response of the limpet, Patella vulgata L., to waters of different salinities. F. mar. biol. Ass. U.K., Vol. 36, pp. I2I-8.

Ballantine, D. \& Morton, J. E., I956. Filtering, feeding and digestion in the lamellibranch Lasaea rubra. F. mar. biol. Ass. U.K., Vol. 35, pp. 24I-74.

Chapman, G., 1955. Aspects of the fauna and flora of the Azores. VI. Density of animal life in the Corallina alga zones. Ann. Mag. nat. Hist., Vol. 8, pp. 80I-5.

Colman, J. S., I933. The nature of the intertidal zonation of plants and animals. F. mar. biol. Ass. U.K., Vol. 18, pp. 435-76.

1940. On the faunas inhabiting intertidal sea-weeds. F. mar. biol. Ass. U.K., Vol. 24, pp. 129-83.

Dixon, M., I943. Manometric methods. I22 pp. Cambridge University Press.

Fischer, P. H., 1940. Sur 1'habitat de Lasaea rubra. Bull. Mus. Hist. nat., Paris, Ser. I, T. I2, pp. 433-5.

Fischer, P. H., Duval, M. \& RAFFY, A., 1933. Études sur les échanges respiratoires des littorines. Arch. Zool. exp. gén., T. 74, pp. 627-34.

Glynne Williams, J. \& Hobart, J., I952. Studies on the crevice fauna of a selected shore in Anglesey. Proc. zool. Soc. Lond., Vol. 122, pp. 797-824.

GrEGG, S. J., 1955. An electromagnetic sorption balance. F. chem. Soc., pp. 1438-9.

JøRGENSEN, C. B., I949. The rate of feeding by Mytilus in different kinds of suspension. F. mar. biol. Ass. U.K., Vol. 28, pp. 333-44.

- 1952. Efficiency of growth in Mytilus edulis and two gastropod veligers. Nature, Lond., Vol. I70, p. 714.

LYSAGHT, A. M., I94I. The biology and trematode parasites of the gastropod Littorina neritoides (L.) on the Plymouth foreshore. F. mar. biol. Ass. U.K., Vol. 25, pp. $4 \mathrm{I}-67$.

Monterosso, B., 1928. Studii cirripedologici III. Persistenza dei fenomeni respiratori nei Ctamalini mantenuti in ambiente subaereo. Boll. Soc. biol. Sper., Vol. 3, pp. $1067-70$.

MoRTON, J. E., I954. The crevice faunas of the upper intertidal zone at Wembury. F. mar. biol. Ass. U.K., Vol. 33, pp. 187-224.

- 1956. The tidal rhythm and action of the digestive system in the lamellibranch Lasaea rubra. F. mar. biol. Ass. U.K., Vol. 35, pp. 563-86.

OldFIELD, E., I955. Observations on the anatomy and mode of life of Lasaea rubra (Montagu) and Turtonia minuta (Fabricius). Proc. malacol. Soc. Lond., Vol. 3I, pp. 226-49.

ORTON, J. H., 1920. Temperature, breeding and distribution in marine animals. F. mar. biol. Ass. U.K., Vol. 12, pp. 339-66. 
PATANÉ, L., I933. Sul comportamento di Littorina neritoides L., mantenuta in ambiente subaereo ed in altre condizione sperimentali. R.C. Accad. Lincei, Ser. 6, Vol. 17, pp. $96 \mathrm{I}-7$.

RoBBIE, W. A., I946. The quantitative control of cyanide in manometric experimentation. F. cell. comp. Physiol., Vol. 27, pp. 181-209.

SEGAL, E., RAO, K. P. \& JAMES, T. W., I953. Rate of activity as a function of intertidal height within populations of some littoral mollusca. Nature, Lond., Vol. I72, p. 1108 .

SOUTHWARD, A. J., I955. On the behaviour of barnacles. II. The influence of habitat and tidal level on cirral activity. F. mar. biol. Ass. U.K., Vol. 34, pp. 423-33.

SOUTHWARD, A. J. \& CRISP, D. J., I954. The distribution of certain intertidal animals around the lrish coast. Proc. R. Irish Acad., Vol. 57 B, pp. I-29.

WHITAKER, D. M., I933. On the rate of oxygen consumption by fertilized and unfertilized eggs. IV. Chaetopterus and Arbacia punctulata. F. gen. Physiol., Vol. 16, pp. 475-95. 